\title{
BENTUK KASKO DAN PENGARUHNYA TERHADAP KAPASITAS VOLUME RUANG MUAT DAN TAHANAN KASKO
}

\author{
Effect of Shape Hull Against Ships Load Capacity Volume Space Ships and Resistance
}

Oleh:

\author{
Moch. Ricky Dariansyah ${ }^{1 *}$, Budhi Hascaryo Iskandar², Yopi Novita² \\ ${ }^{1}$ Mahasiswa Program Studi Teknologi Perikanan Laut \\ ${ }^{2}$ Staf Pengajar Program Studi Teknologi Perikanan Laut \\ *Korespondensi: ricky.nautical@yahoo.com
}

\begin{abstract}
ABSTRAK
Penelitian ini bertujuan untuk menganalisis perbandingan nilai total volume ruang muat hasil penangkapan ikan dengan tahanan kapal pada lima tipe kasko kapal yaitu flat bottom, akatsuki bottom, hard chin bottom, round flat bottom, dan round bottom. Analisis nilai total ruang muat hasil penangkapan ikan dilakukan melalui perhitungan rumus gabungan simpson 1 dan simpson 2, dimana jarak antara gading ataupun frame space dengan menggunakan perhitungan rumus dari kelas Biro Klasifikasi Indonesia (BKI), sedangkan analisis perhitungan tahanan kapal didapat dari berbagai perhitungan standar tahanan kapal, kemudian dari hasil masing-masing analisis total volume ruang muat hasil penangkapan ikan dengan tahanan kapal dibandingkan untuk mendapatkan nilai efektifitas serta efesiensi dimana nilai volume ruang muat hasil penangkapan ikan besar dengan tahanan kapal kecil dari bentukan kasko lambung kapal tersebut, dengan ukuran kapal yang sama.
\end{abstract}

Kata kunci: bentuk lambung, kapal ikan, lambung.

\begin{abstract}
This study aimed to analyze the comparative value of the total volume of load space with the inmate results of fishing vessels in five types, namely flat bottom boat Kasko, Akatsuki bottom, hard chin bottom, round flat bottom and round bottom. Analysis of the total value of load space results fishing is done by calculating the formula combined simpson 1 and Simpson 2, where the distance between the ivory or frame space by using a calculation formula of class Classification Bureau Indonesia (BKI), while the analysis of the calculation of ship resistance obtained from a variety of standard calculations custody the ship, then the results of each analysis the total volume of load space results fishing ship resistance compared to getting the value of the effectiveness and efficiency which the value of the volume of the cargo the results of catching big fish with prisoners small ship formations Kasko hull, with the size of the vessel same.
\end{abstract}

Keywords: hull form, fishing vessel, bottoms.

\section{PENDAHULUAN}

Berdasarkan hasil kajian Rouf (2004), bentuk kasko kapal penangkap ikan di Indonesia sangat bervariasi, akan tetapi tidak menunjukkan kecenderungan tertentu berdasarkan metode pengoperasian alat tangkap. Bentuk kasko kapal hanya ditentukan berdasarkan kebiasaan para pembuat kapal. Pada kenyataannya, bila bentuk kasko kapal tidak sesuai dengan kebutuhan, maka efektifitas dan efisiensi operasional kapal kurang optimal. Mengacu pada Fyson (1985) yang menyatakan bahwa salah satu faktor penentu desain kapal penangkap ikan adalah metode pengoperasian alat tangkap. Tiap metode 
pengoperasian alat tangkap, membutuhkan desain kapal yang dapat mendukung keberhasilan pengoperasian alat tangkap tersebut. Salah satu bagian dari kapal yang menentukan kemampuan operasional kapal adalah bentuk kasko (hull) kapal. Rouf (2004) menyatakan bahwa bentuk kasko kapal penangkap ikan yang umum digunakan di Indonesia adalah bentuk $U$-bottom, round bottom, round flat bottom, dan akatsuki. Bentuk kasko kapal erat kaitannya dengan kemampuan stabilitas, manouverability dan kecepatan kapal. Seyogyanya, kapal dengan metode pengoperasian yang berbeda akan memiliki bentuk kasko yang berbeda pula

Mengacu pada metode pengoperasian, Fyson (1978) menyatakan bahwa terdapat tiga kelompok metode pengoperasian kapal penangkap ikan yaitu: kelompok kapal encircling gear, static gear dan towed/dragged gear. Kelompok kapal encircling gear lebih membutuhkan desain kasko kapal yang mampu mengeliminir tahanan gerak dan manouverability yang tinggi. Adapun kelompok kapal static gear lebih membutuhkan desain kasko kapal yang memiliki stabilitas yang tinggi. Lain halnya dengan kelompok kapal towed/dragged gear, membutuhkan desain kasko yang mampu mengeliminir tahanan gerak dan stabilitas yang tinggi. Oleh karena itu, seyogyanya bentuk kasko kapal berbeda-beda untuk tiap metode pengoperasian alat tangkap.

Tiap bentuk kasko kapal memiliki kapasitas muat yang berbeda. Bentuk kasko kapal semakin mendekati bentuk kotak (istilah lainnya adalah bentuk kasko gemuk), maka kapasitas muatnya akan semakin besar. Sebaliknya jika bentuk kasko kapal semakin ramping maka kapasitas muatnya semakin sedikit. Bentuk kasko gemuk atau ramping pada akhirnya akan menentukan besar kecilnya displacement kapal, yang pada akhirnya akan menentukan besar kecilnya luas penampang melintang kapal dan wet surface area. Luas penampang melintang dan wet surface area kapal adalah dua dari tiga faktor penentu besar kecilnya tahanan kasko kapal.

Oleh karena itu, perlu suatu kajian untuk dapat menentukan bentuk kasko kapal yang sesuai dengan metode pengoperasian alat tangkap yang digunakan. Kajian ini adalah merupakan tahap awal dalam upaya untuk mendapatkan bentuk lambung kapal yang sesuai dengan metode pengoperasian alat tangkap yang akan dioperasikannya. Untuk mencapai upaya tersebut, maka pada tahap awal perlu dilakukan kajian terhadap pengaruh bentuk kasko terhadap kapasitas muat dan tahanan kasko yang dihasilkan. Tujuan penelitian adalah 1) membandingkan kapasitas muat palka optimal dari tiap bentuk kasko kapal, dan 2) membandingkan tahanan kasko kapal dari tiap bentuk kasko kapal.

\section{METODE PENELITIAN}

Penelitian dilakukan dengan menggunakan metode simulasi numerik. Dalam tahap awal kajian, ditetapkan lima bentuk kasko kapal yang umum digunakan pada kapal-kapal penangkap ikan di Indonesia, yaitu U-bottom, Round bottom, Round flat bottom, Akatsuki bottom, dan Hard chin bottom, yang disajikan pada gambar 1 .

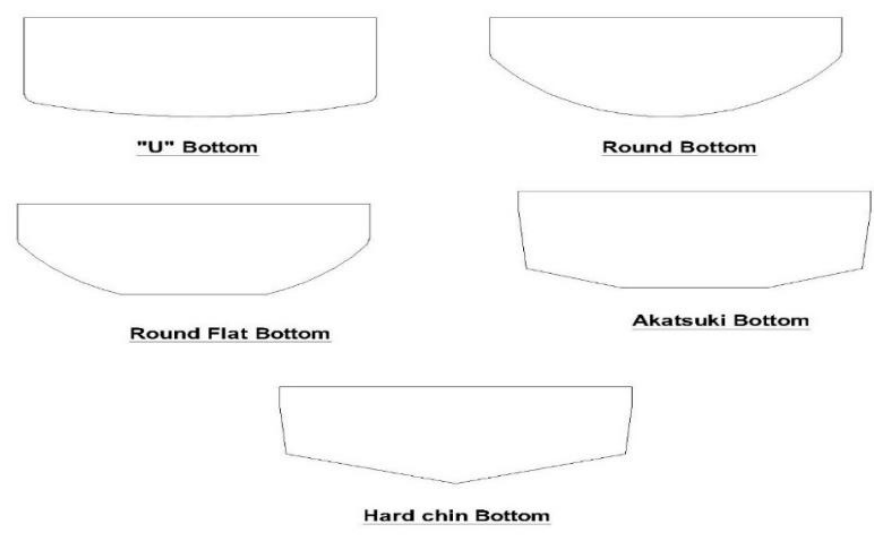

Gambar 1 Bentuk kasko Lambung kapal 
Penggunaan kelima bentuk kasko tersebut mengacu pada hasil kajian Rouf (2004). Selanjutnya dibuat body plan dari kelima bentuk kasko tersebut dengan dimensi LOA (panjang kapal total), lebar (B) dan tinggi (D) dan sarat (d) kapal yang sama. Penetapan ukuran dimensi kapal tersebut adalah mengacu pada kapal penangkap ikan ukuran 30 GT. Dimensi utama dan gambar penampang utuh kapal di sajikan pada Tabel 1 dan Gambar 2. Penggunaan dimensi kapal ukuran 30 GT dikarenakan dalam pengoperasian kapal penangkap ikan banyak digunakan dengan ukuran dan dimensi dengan batasan ukuran tersebut, selain itu mengacu pada program pembangunan 1000 unit kapal yang dilaksanakan pada instansi negara (Kementerian Kelautan dan Perikanan) yang pelaksanaanya beroperasi diseluruh perairan Indonesia dengan keadaan dan kondisi perairan yang berbeda-beda sehingga perbedaan dari kelima bentuk lines plan kapal yang dirancang adalah pada bentuk kasko kapal (Gambar 3).

Tabel 1 Ukuran dimensi utama kapal

\begin{tabular}{cc}
\hline Keterangan & Panjang (m) \\
\hline (LOA) Panjang Seluruh Kapal & 18,50 meter \\
(LWL) Panjang Garis Air & 16,75 meter \\
(LBP) Panjang Tegak haluan dan Buritan & 15,97 meter \\
(Depth) Tinggi kapal & 1,80 meter \\
(Draft) Sarat Kapal & 1,30 meter \\
(Breatdh) Lebar Kapal & 4,40 meter \\
\hline
\end{tabular}
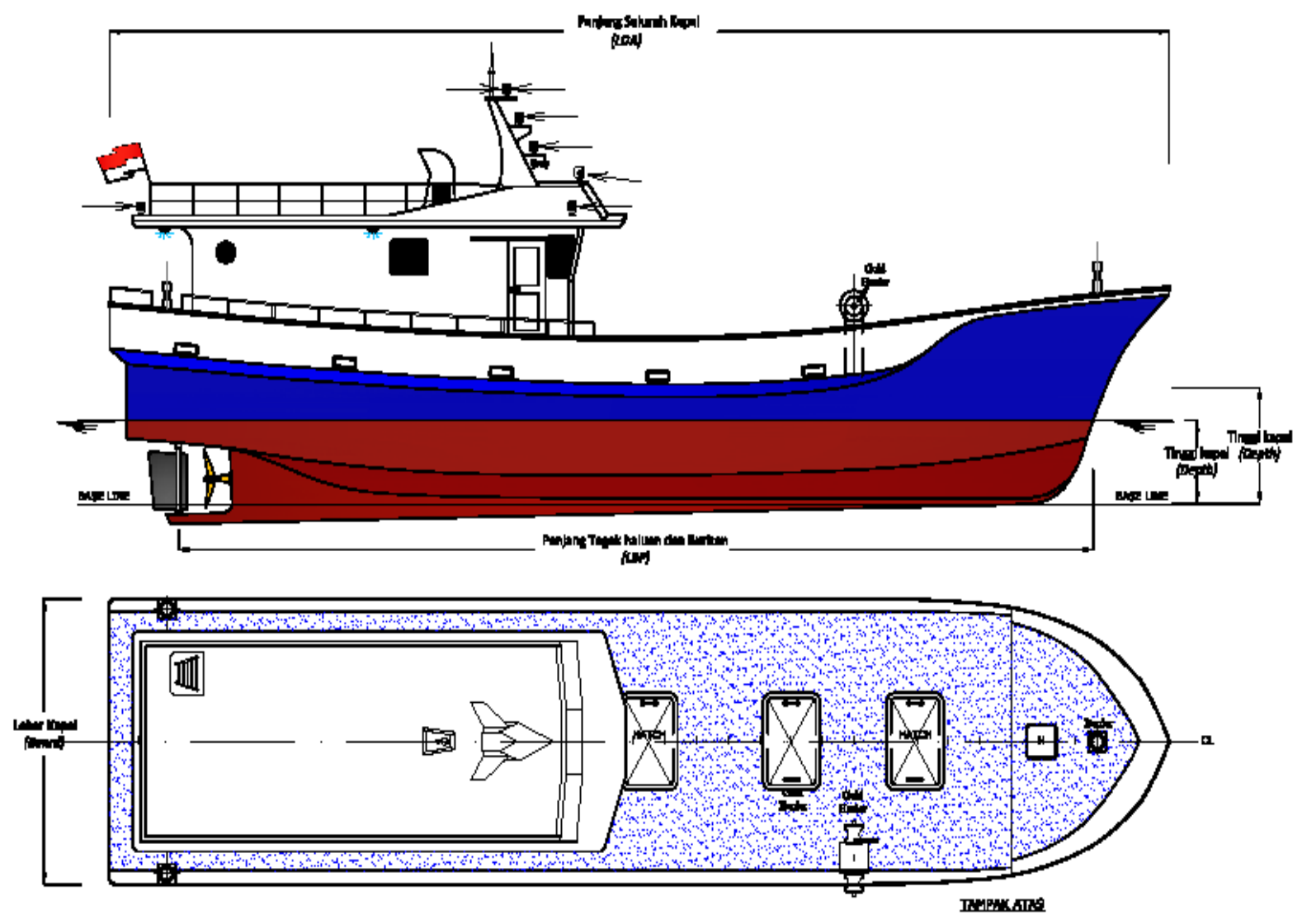

Gambar 2 Penampang utuh kapal 


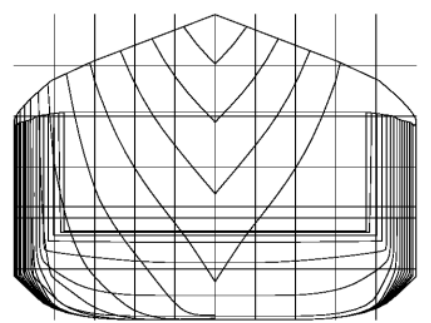

"U” Bottom

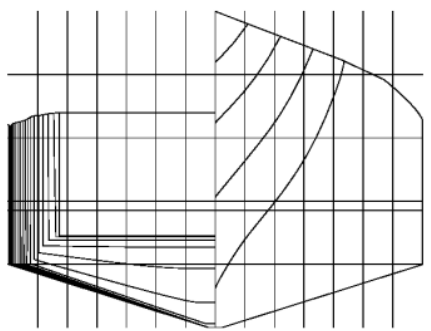

Hard Chin Bottom

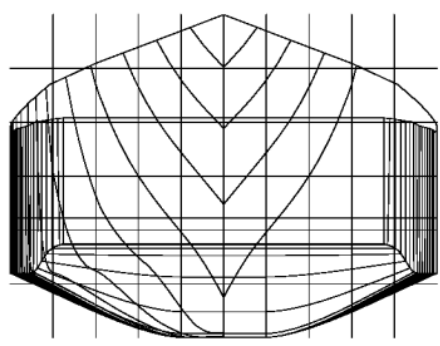

Akatsuki Bottom

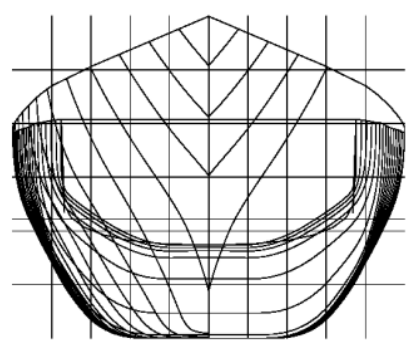

Round Flat Bottom

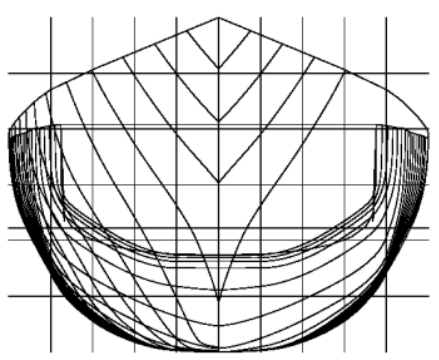

Round Bottom

Gambar 3 Body plan

Data yang dibutuhkan untuk mencapai tujuan penelitian adalah data yang terkait dengan kapasitas muat kapal yang terdiri dari: coefficient of block $(\mathrm{Cb})$, volume displacement $\left(\mathrm{m}^{3}\right)$, dan volume palka $\left(\mathrm{m}^{3}\right)$; serta data yang terkait dengan tahanan kasko yang terdiri dari: wet surface area (WSA), dan tahanan kasko. Kesemua data tersebut diperoleh dengan menggunakan software pengolah data naval architechture. Beberapa persamaan matematik yang digunakan adalah sebagai berikut:

Rumus coefficient of block $(\mathrm{Cb})$, menunjukkan perbandingan antara nilai volume displacement kapal dengan volume bidang empat persegi panjang yang mengelilingi tubuh kapal. Menurut Poehls (1979) persamaan $\mathrm{Cb}$ yaitu:

$$
\mathrm{Cb}=\frac{\Delta}{L p p \times B \times T \times 1,025}
$$

dengan:

$$
\begin{aligned}
\text { Lpp } & =\text { panjang perpendicular }(\mathrm{m}) \\
\mathrm{B} & =\text { lebar kapal }(\mathrm{m}) \\
\mathrm{T} & =\operatorname{draft}(\mathrm{m}) \\
\Delta & =\text { volume displacement }\left(\mathrm{m}^{3}\right) .
\end{aligned}
$$


Volume displacement $\left(\mathrm{m}^{3}\right)$, berat benaman adalah berat zat cair yang dipindahkan oleh badan kapal yang berada di bawah permukaan cairan dimana kapal berada, atau bisa dikatakan bahwa displacement adalah berat kapal beserta isinya.

$\nabla \operatorname{disp}=\mathrm{LBP} \times \mathrm{B} \times \mathrm{T} \times \mathrm{Cb}$

Volume palka $\left(\mathrm{m}^{3}\right)$, adalah luasan ruang palka yang merupakan ruang kosong untuk menampung ikan atau hasil tangkapan. Didalam perhitungan volume kapal sama seperti halnya menghitung bangun ruang lainya, akan tetapi didalam menghitung luasan dengan menggunakan rumus simpson, dikarenakan bentukan dari permukaan tidak teratur. Berikut beberapa rumus simpson 1 sampai dengan simpson 2.
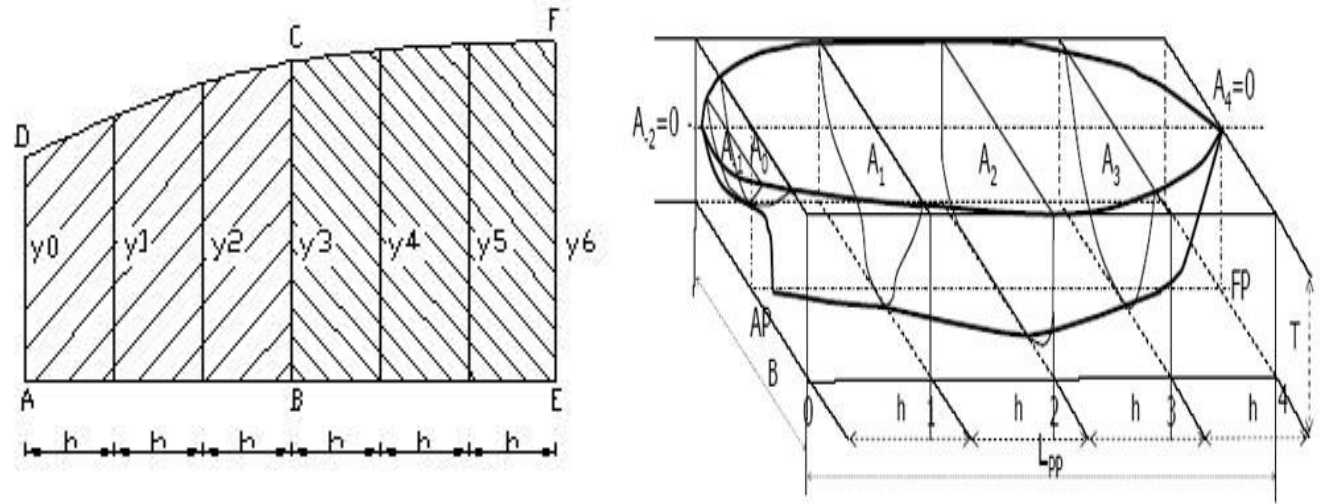

Gambar 4 Luasan perhitungan simpson

\section{Simpson 1}

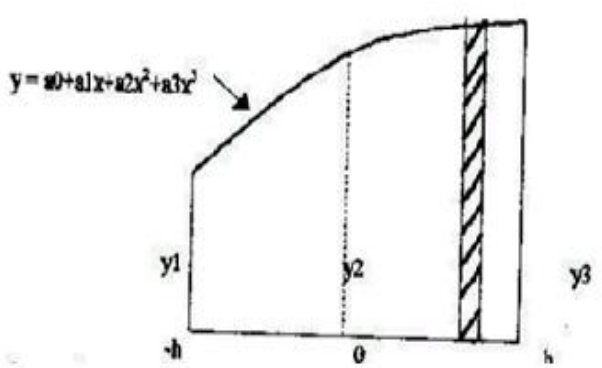

Untuk mudahnya diambil :

$$
\begin{aligned}
& \mathrm{x} 0=-\mathrm{h} \\
& \mathrm{x} 1=0 \\
& \mathrm{x} 2=\mathrm{h}
\end{aligned}
$$

Maka:

$\mathrm{y} 0=\mathrm{ax} 02+\mathrm{bx} 0+\mathrm{c}=\mathrm{ah} 2-\mathrm{bh}+\mathrm{c}$ dan seterusnya. Misalkan luas dapat dinyatakan sebagai:

$$
\mathrm{A}=\mathrm{Ly} 0+\mathrm{My} 1+\mathrm{Ny} 2
$$

Dengan y0, y1 dan y2 adalah:

$$
\begin{aligned}
& A=L\left(a h^{2}-b h+c\right)+M c+N\left(a h^{2}+b h+c\right)= \\
& a h^{2}(L+N)+b h(-L+N)+c(L+M+N)
\end{aligned}
$$

Kedua luas ini harus sama besar, sehingga didapat 3 persamaan berikut:

koefisien untuk a: $h^{2}(L+N)=\frac{2}{3} h^{3} \rightarrow L+N=\frac{2}{3} h$

koefisien untuk b: $h(-L+N)=0 \rightarrow-L+N=0$

koefisien untuk c: $L+M+N=2 h$

Dari 3 persamaan ini didapat $L=\frac{1}{3} h, \quad M=\frac{4}{3} h, \quad N=\frac{1}{3} h$ 
Jika hanya dipakai 1 parabola dengan jarak ordinat h, luas parabola A menjadi:

$\mathrm{A}=1 / 3[h(\mathrm{y} 0+4 \mathrm{y} 1+\mathrm{y} 2)]$

Simpson 2

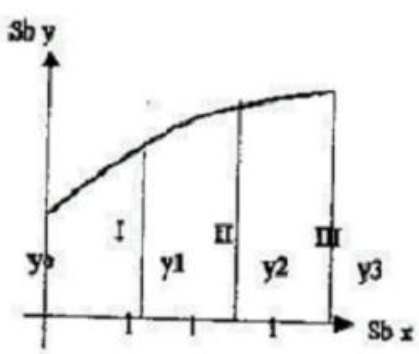

Jika hanya dipakai 1 polinom pangkat 3 dengan jarak ordinat h, luas polinom A menjadi:

$$
\mathrm{A}=3 / 8[h(\mathrm{y} 0+3 \mathrm{y} 1+3 \mathrm{y} 2+\mathrm{y} 3)]
$$

Tahanan kasko, yang merupakan sebuah gaya fluida yang bekerja pada badan kapal yang sedemikian rupa sehingga bekerja melawan gerakan kapal. Tahanan kapal (resistance) didefinisikan sebagai :

$$
\mathrm{R}=1 / 2 . \mathrm{C} . \rho \text {. V2.S }
$$

dengan:

$\mathrm{C}=$ adalah koefisien tahanan $\left(10^{3} \mathrm{CT}=\mathrm{CR}+\mathrm{CF}+\mathrm{CA}+\mathrm{CAA}+\mathrm{CAS}\right)$

$\mathrm{V}=$ kecepatan kapal

$\rho=$ masa jenis air laut, dan

$\mathrm{S}=$ luas permukaan basah kapal.

Wet surface area (WSA), adalah luas permukaan badan kapal yang tercelup dalam air.

Stot $=\mathrm{S}+$ Sapp

$\mathrm{S}=(\operatorname{LWL} \times(2 d B)(C \mathrm{~m})) \times((0,453 \times 0,44225 C b-0,2862 C \mathrm{~m})+(-0,003467 \times B / d+0,3696 C w))+$ $(2,38 \times \mathrm{ABT} / \mathrm{Cb})$

dengan:

ABT $=$ Cross sectional area of bulb in FP; 0 (Tidak memakai bulb)

Sapp = luasan dari daerah tonjolan (kemudi, boss dan propeller).

Koefisien midship (Coefisien of Midship), menunjukkan perbandingan luas area penampang melintang tengah kapal dengan bidang empat persegi panjang yang mengelilingi luas area tersebut. Menurut Van Lameren:

$$
\mathrm{Cm}=0.9+0.1 \sqrt{\mathrm{Cb}}
$$

Menurut Poehls (1979):

$$
\mathrm{Cm}=0,93+(0,08 \times \mathrm{Cb})
$$

Koefisien waterline (Coefisien of Waterline), nilai yang menunjukkan besarnya luas area penampang membujur tengah kapal dibandingkan dengan bidang empat persegi panjang yang mengelilingi luas area tersebut. Persamaan menurut Poehls (1979) adalah sebagai berikut:

$$
\begin{aligned}
& \mathrm{Cw}=(0,70 \times \mathrm{Cb})+0,30 \ldots \ldots \ldots \ldots \ldots \ldots \\
& \mathrm{Cw}=0,95 \times \mathrm{Cp}+0,17 \sqrt[3]{C p}(10) .
\end{aligned}
$$

Koefisien prismatik (Coefficien of Prismatic), perbandingan antara volume badan kapal yang ada di bawah permukaan air dengan volume sebuah prisma dengan luas penampang midship (Am) dan panjang Lwl. Persamaan koefisien prismatik dapat dilihat sebagai berikut:

$\mathrm{Cp}=\frac{\nabla}{\mathrm{A} \otimes \cdot \mathrm{Lwl}}$

dengan:

$\mathrm{V}=$ Isi. 
$\mathrm{A} \otimes=$ Luas penampang gading besar (luas midship)

$\mathrm{Lwl}=$ Panjang garis air.

Koefisien prismatik (Coefficient of Prismatic), nilai yang menunjukan perbandingan antara volume displacement kapal dengan volume yang dibentuk oleh luas area penampang melintang tengah kapal dengan panjang kapal pada waterline.

\section{HASIL}

\section{Kapasitas Muat}

Berdasarkan hasil perhitungan naval architecture, nilai coefficient of fineness, volume displacement, dan volume palka disajikan pada bentuk tabel. Menurut Fyson (1985) coefficient of fineness terdiri dari coefficient of block $(\mathrm{Cb})$, coefficient of Prismatic $(\mathrm{Cp})$, coefficient of midship $(\mathrm{Cm})$, dan coefficient of waterline $(\mathrm{Cw})$.

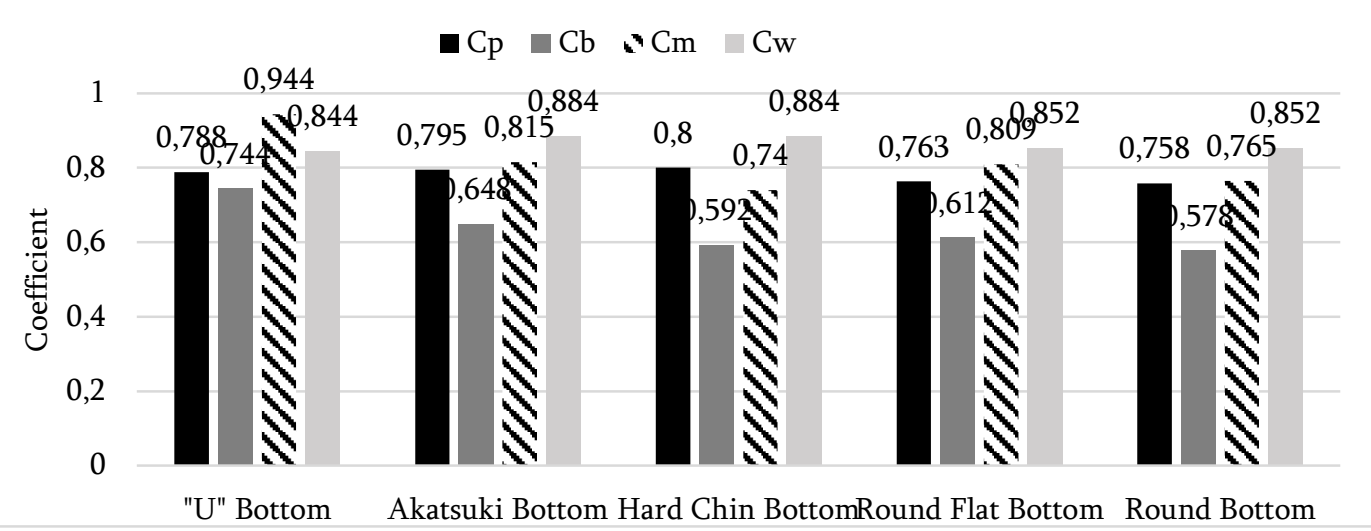

Gambar 5 Kisaran nilai coefficient of fineness pada setiap lambung kapal

Pada Gambar 5 terlihat bahwa nilai Cp dan Cw dari keempat bentuk kasko kapal relatif sama dengan batasan nilai $C p(0,788$ - 0,800) sedangkan untuk $C w(0,844-0,852)$ yang berbeda hanyalah pada pada kasko round bottom $(0,852)$. Lain halnya dengan nilai $\mathrm{Cm}$, kelima bentuk kasko memiliki nilai yang berbeda $(0,740-0,944)$. Nilai Cm terbesar dimiliki oleh bentuk kasko U-bottom $(0,944)$. Adapun bentuk kasko akatsuki bottom - round flat bottom dan hard chin bottom-round bottom memiliki kecenderungan nilai $\mathrm{Cb}$ yang bervariasi $(0,578-0,744)$, yang terbesar pada kasko U-bottom (0,744). Pada nilai Cw dari keempat bentuk kasko kapal relatif sama $(0,758-0,795)$ yang berbeda hanyalah pada pada kasko hard chin bottom $(0,800)$.

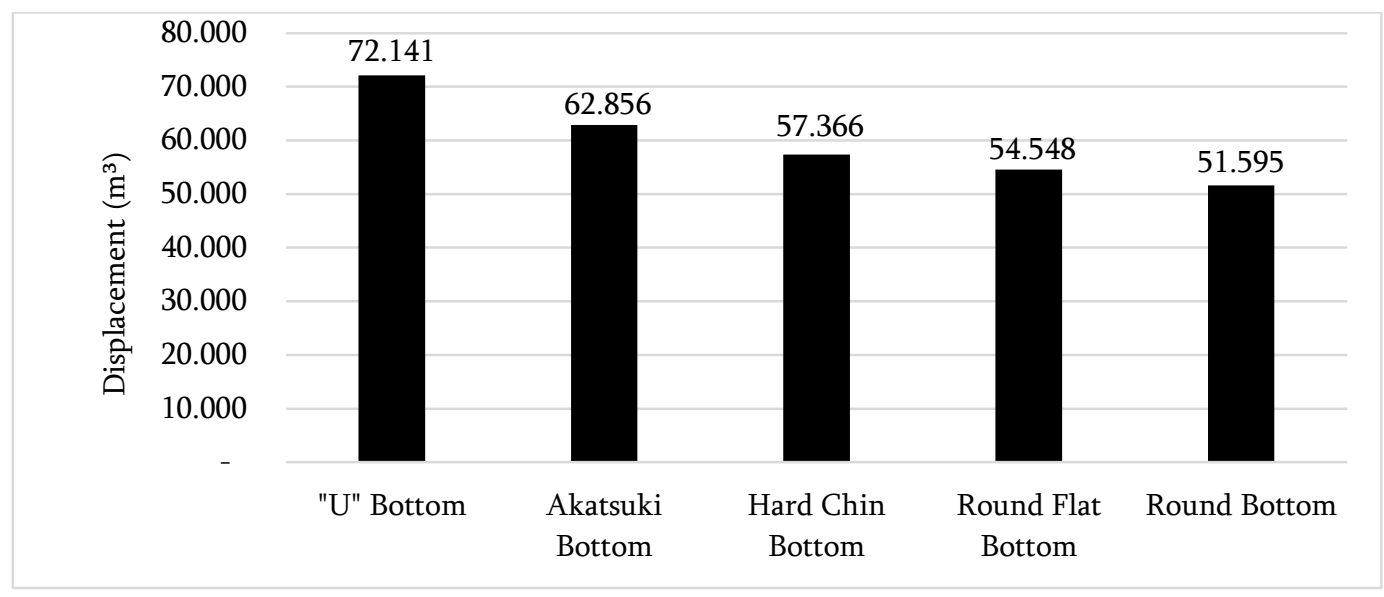

Gambar 6 Kisaran nilai volume dispalcement kapal pada setiap lambung kapal 
Berdasarkan besaran volume displacement kapal (Gambar 6), terlihat bahwa kasko berbentuk $U$-bottom memiliki volume displacement terbesar $\left(72.141 \mathrm{~m}^{3}\right)$ jika dibandingkan dengan keempat kasko kapal lainnya. Adapun volume displacement kapal terkecil dimiliki oleh kasko berbentuk round bottom $\left(51.595 \mathrm{~m}^{3}\right)$.

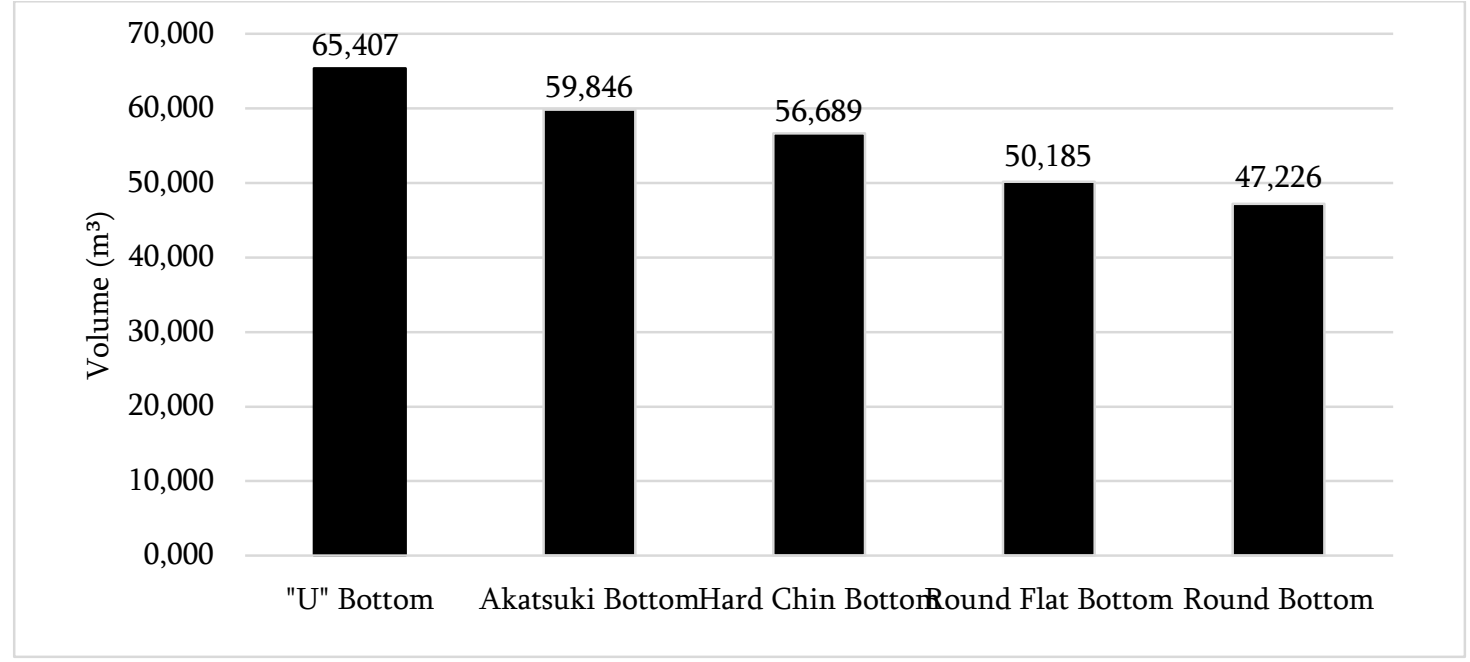

Gambar 7 Kisaran volume ruang muat

Gambar 7 menunjukkan perbandingan volume ruang muat hasil tangkapan (palka) yang dimiliki oleh masing-masing bentuk kasko kapal. Untuk menghitung volume kapasitas ruang muat untuk tempat palka adalah kapal di bagi menjadi beberapa kompartemen sesuai jarak gading (frame) yang ditetapkan. Penetapan jarak gading dengan menggunakan perhitungan peraturan Biro klasifikasi Indonesia (2007), dengan jarak antar gading 5,5 meter (dapat dilihat pada Gambar 8). Jumlah gading atau frame diperkirakan sebanyak 35 bagian yang dimulai dari titik nol pada poros daun kemudi.
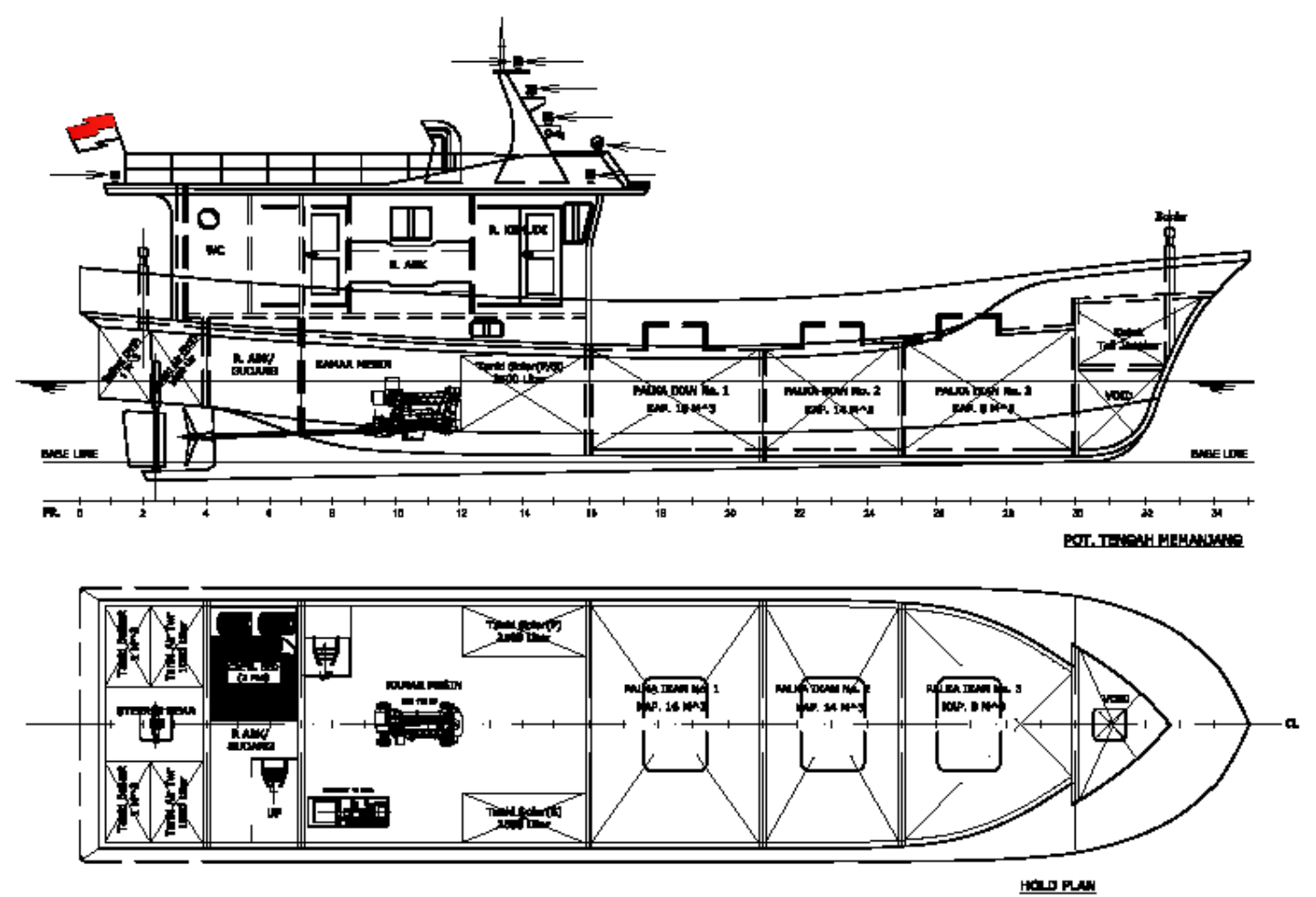

Gambar 8 Perencanaan ruang palkah 
Palka pertama dimulai pada ordinat 16 sampai dengan ordinat 21. Palka kedua pada ordinat 21 sampai dengan ordinat 25, dan palka ketiga terletak pada ordinat 25 sampai dengan ordinat 30. Selanjutnya setiap palka tersebut dihitung luasan penampang palka, yang nantinya setelah dikalikan dengan panjang palka, maka akan diperoleh volume palka.

Perhitungan terhadap volume palka optimal yang dapat disediakan di tiap kasko kapal, terlihat bahwa bentuk kasko $U$-bottom memiliki volume palka terbesar $\left(65.407 \mathrm{~m}^{3}\right)$, jika dibandingkan dengan bentuk kasko lainnya. Adapun bentuk kasko round bottom memiliki volume palka terkecil $\left(47.226 \mathrm{~m}^{3}\right)$.

\section{Tahanan Kasko}

Kajian tahanan kasko dilakukan dengan mengamati nilai WSA (Wet surface area) dan tahanan kasko itu sendiri. Hal ini dikarenakan nilai WSA (Wet surface area) dan CR akan menentukan nilai tahanan kasko. Nilai WSA dan tahanan kasko disajikan pada Gambar 9 dan Gambar 12.

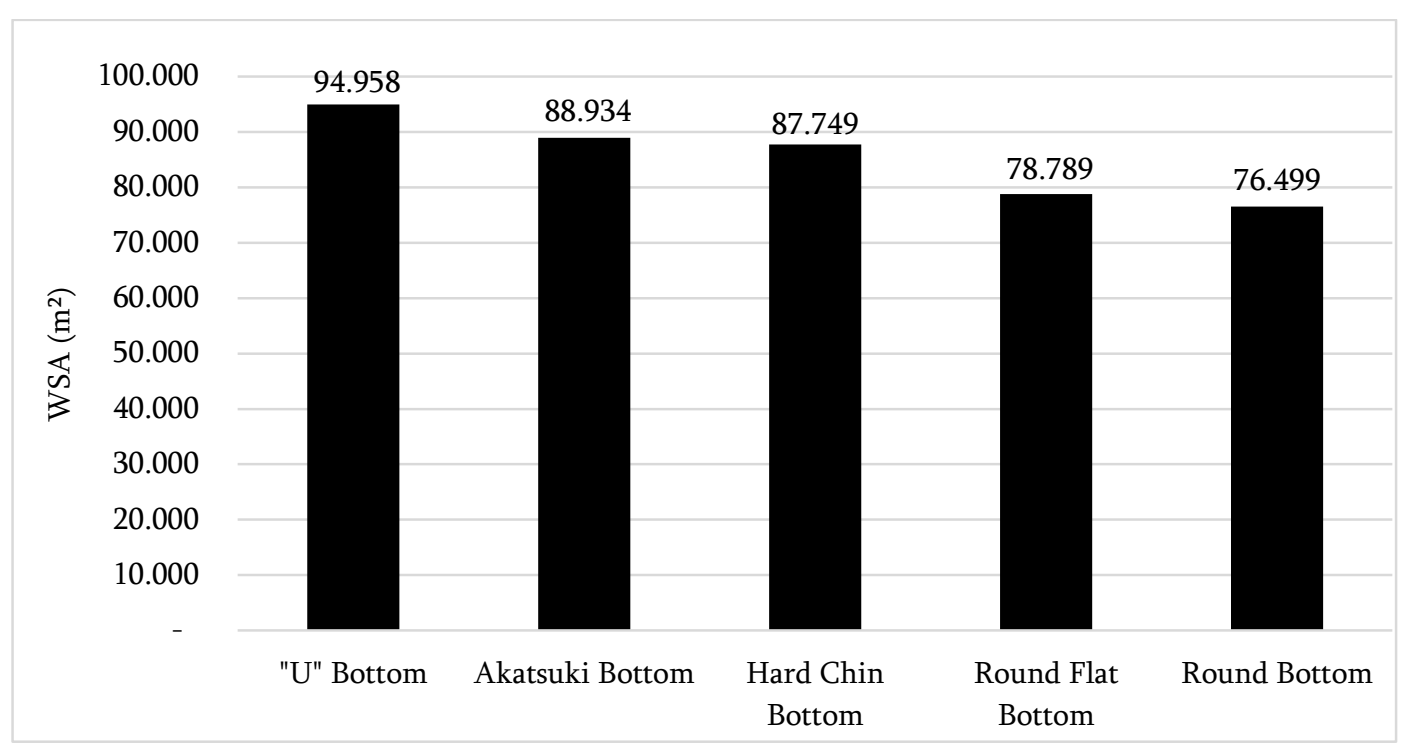

Gambar 9 Nilai WSA (Wet surface area) pada setiap kasko kapal

Nilai WSA terbesar dimiliki oleh kasko berbentuk $U$-bottom yaitu sebesar $94.958 \mathrm{~m}^{2}$. Adapun kasko berbentuk round bottom memiliki nilai WSA terkecil yaitu sebesar $76.499 \mathrm{~m}^{2}$. Akan tetapi bentuk kasko akatsuki bottom dan hard chin bottom memiliki nilai WSA yang relatif sama.

Tahanan kapal dari setiap tipe kasko kapal dapat diperoleh dengan menggunakan grafik Guldhammer dan Harvald yang disajikan pada Gambar 10. Dari grafik tersebut didapatkan nilai koreksi yang dihitung dari hasil Froude number (Fn) yakni dengan ketetapan kecepatan dinas yang digunakan adalah 7 knot. Sehingga nilai Froude number yang diperoleh adalah sebesar 0,282. Berdasarkan nilai Fn tersebut, selanjutnya akan diperoleh nilai koreksi LCB standar sebesar 3,121\%. Kemudian barulah nilai CR dihitung untuk nilai perbedaan tiap 1\% lokasi LCB didepan LCB kapal standard dengan nilai $\gamma 10^{3} \mathrm{C}_{\mathrm{R}} / \gamma$ LCB sebesar 0,712 hasil tersebut dapat dilihat pada Gambar 11 .

Nilai LCB maupun koreksi CR untuk kelima bentuk kasko adalah sama. Hal ini dikarenakan panjang kapal (L) kelima desain kapal yang disimulasikan pada kelima bentuk kasko kapal adalah sama. Sehingga nilai Fn-nya pun sama. Pada perhitungan selanjutnya dilakukan untuk mendapatkan nilai tahanan kasko dari kelima bentuk kasko kapal. Berhubung pengujian hanya pada tipe kasko kapal, maka ada beberapa koreksi yang diabaikan seperti lunas bilga, daun kemudi, koreksi bentuk haluan kapal. 


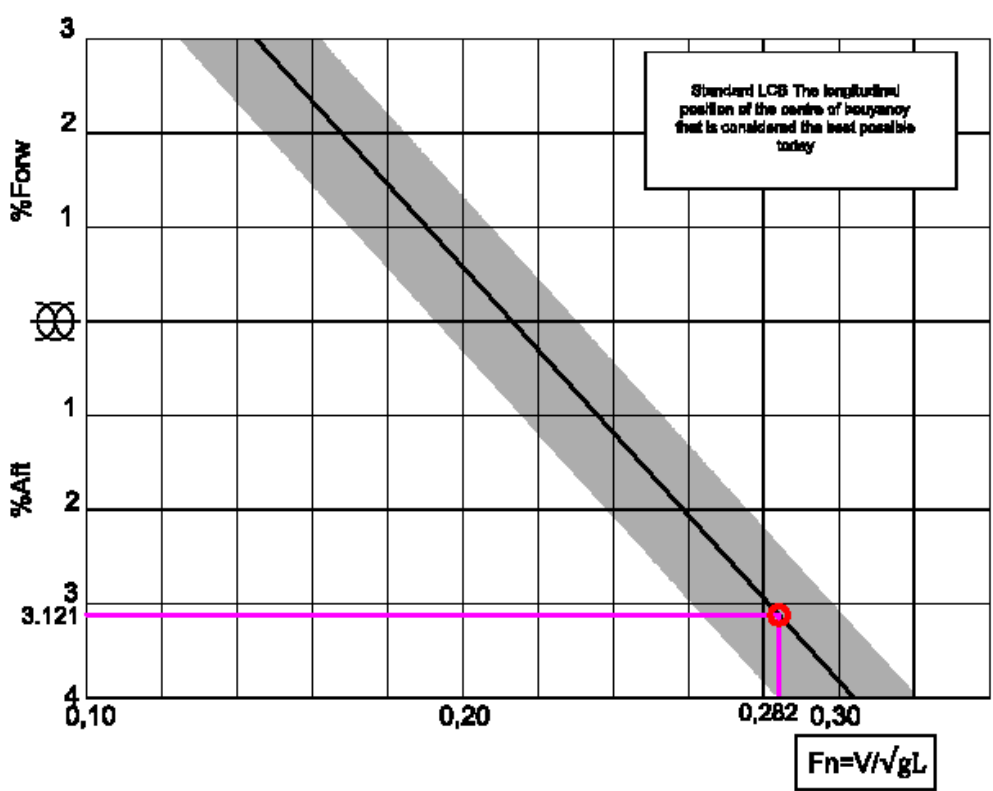

Gambar 10 LCB kapal Standart Guldhammer \& Harvald

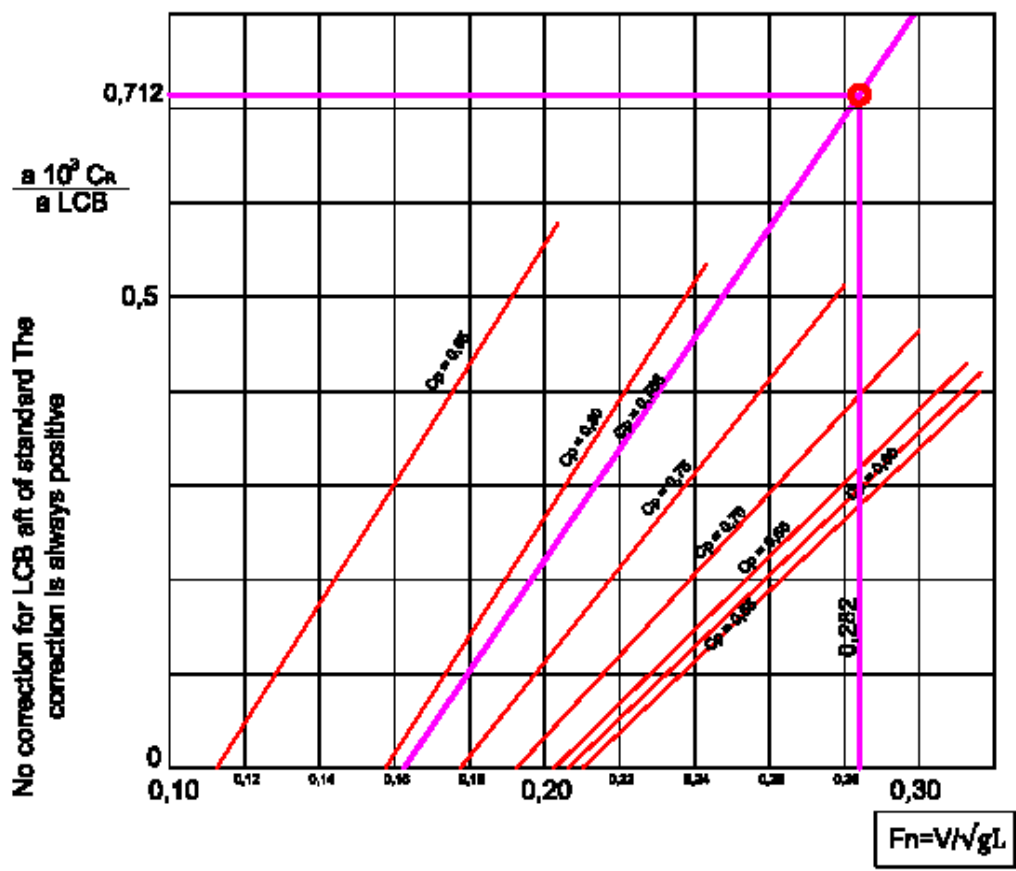

Gambar 11 Koreksi CR untuk tiap 1\% perbedaan lokasi LCB didepan LCB kapal standard

Tahanan kasko kapal yang diperoleh dari hasil perhitungan terhadap kelima bentuk kasko menunjukkan nilai yang berbeda. Akan tetapi tahanan kasko U-bottom dan hard chin bottom memiliki nilai tahanan kasko yang hampir sama. Nilai tahanan kasko keduanya hanya selisih 0,014 ton. Round bottom adalah bentuk kasko yang menghasilkan tahanan kasko terkecil yaitu 0,931 ton. 


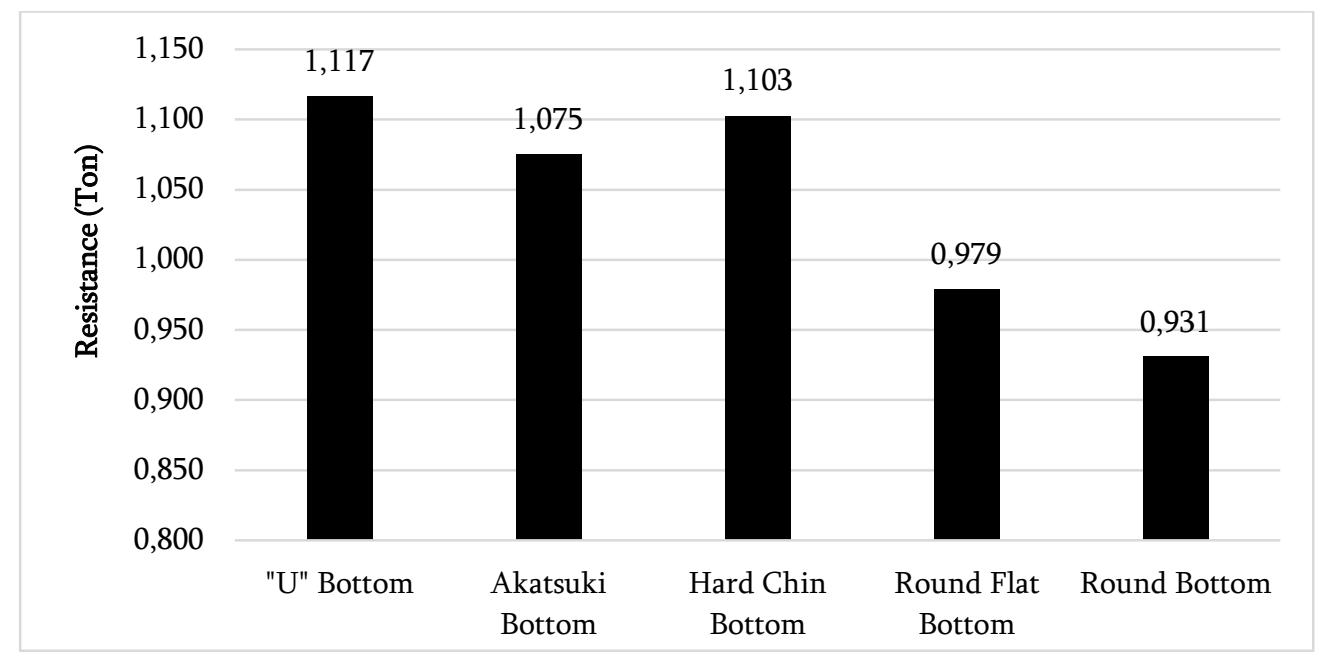

Gambar 12 Nilai tahanan kasko kapal

\section{PEMBAHASAN}

Nilai Cp dan Cw dari kelima bentuk kasko kapal relatif sama dengan batasan nilai untuk Cp adalah 0,788 - 0,800 dan untuk $\mathrm{Cw}$ adalah 0,844 - 0,852. Hal tersebut dikarenakan berpengaruh dari besaran ukuran utama kapal yang sama terutama pada besaran nilai panjang waterline yang sama yaitu sebesar 16,75 m, sehingga perubahan nilai Cp maupun $\mathrm{Cw}$ tidak terlalu besar perubahannya. Kelima bentuk kasko memiliki nilai $\mathrm{Cb}$ yang berbeda, yang terbesar dimiliki oleh tipe kasko $U$-bottom sebesar 0,744 karena dipengaruhi oleh bentukan kasko yang lebih kotak (gemuk) dibandingkan dengan tipe kasko lainnya. Nilai $\mathrm{Cm}$ terbesar dimiliki oleh bentuk kasko $U$-bottom sbesar 0,944, karena memiliki nilai $\mathrm{Cb}(\mathrm{Cm}=0,93+(0,08 \times \mathrm{Cb}))$ dan memiliki bentukan kasko yang lebih besar dibandingkan dengan tipe kapal lainnya.

Bentuk kasko akatsuki bottom - round flat bottom, hard chin bottom, dan round bottom memiliki kecenderungan perbandingan nilai koefisien yang sama, karena perubahan bentukan kasko tidak terlalu signifikan perubahannya, sehingga dari tipe kasko tersebut memiliki nilai perbandingan koefisien yang tidak terlalu jauh berbeda. Dari hasil pembahasan diatas dampak yang akan terjadi adalah semakin besar nilai koefisien terutama pada nilai koefisien blok (Coefficien Block) maka akan semakin besar pula nilai hambatan yang akan dihasilkan dari setiap tipe kasko. Nilai coefficient of fineness mendekati 1, menunjukkan bahwa kapal mendekati bentuk kotak atau dikatakan kapal memiliki bentuk gemuk. Sebaliknya, semakin menjauhi nilai 1, kapal dikatakan memiliki bentuk yang ramping.

Kasko berbentuk $U$-bottom memiliki volume displacement terbesar $\left(72.141 \mathrm{~m}^{3}\right)$ dibandingkan dengan tipe kasko lainnya dikarenakan bentukan serta luasan penampang pada lambung kapal yang lebih besar, berbeda halnya dengan round bottom memiliki volume displacement terterkecil (51.595 $\mathrm{m}^{3}$ ). Sehingga akan mempengaruhi bentukan serta volume ruang palka ataupun muat yang akan diperoleh dari bentukan tiap kasko tersebut.

Wet surface area (WSA) adalah luas permukaan badan kapal yang tercelup untuk tiap-tiap sarat kapal. Nilai WSA terbesar masih dimiliki oleh kasko berbentuk $U$-bottom yaitu sebesar $94,958 \mathrm{~m}^{2}$. Semakin besar nilai WSA maka nilai tahanan gerak semakin besar pula, kasko berbentuk round bottom memiliki nilai WSA terkecil yaitu sebesar 76,499 $\mathrm{m}^{2}$, pengaruh dari besarnya nilai WSA ini karena besarnya nilai $\mathrm{Cb}$ (Coefisien of Block), dimana akan mempengaruhi besaran bentukan kasko kapal sehingga samakin besar pula permukaan badan kapal yang tercelup dibawah permukaan air WSA. 
Tahanan kasko U-bottom dan hard chin bottom memiliki nilai tahanan kasko yang hampir sama. Besarnya nilai tahanan kasko ini dipengaruhi oleh besarnya nilai koefisien. Adapun tahanan kasko yang terkecil dari kelima tipe kasko adalah Round bottom dengan nilai tahanan kasko yaitu 0,931 ton. Kaitannya antara WSA dengan tahanan kasko adalah berpengaruh pada besarnya hambatan (Resistance) yang akan dihasilkan terhadap hambatan gesek (Frictional Resistance) terhadap air laut sebagai media fluida dalam hambatan yang dihasilkan, besarnya nilai tahanan kasko ini akan berpengaruh terhadap eksistensi kapal didalam kecepatan operasional menuju area penangkapan ikan (Fishing ground) serta penggunaan mesin induk yang kaitannya dengan penggunaan bahan bakar, dimana dalam pemilihan kasko selain dari sisi stabilitas yang baik juga harus mengacu pada biaya pengoperasian sekecil mungkin untuk memperoleh keuntungan sebesar-besarnya.

Dalam pemilihan bentuk kasko pada perancangan sebuah kapal ikan harus sesuai dan benarbenar sesuai dengan fungsinya, artinya pada bentukan kasko kapal sebesar mungkin dapat menampung hasil tangkapan, akan tetapi sekecil mungkin tahanan kasko yang akan dihasilkan. Maka dari perhitungan yang ada serta perbandingan dari kelima bentukan kasko tersebut yang paling ideal adalah kapal dengan tipe kasko Akatsuki bottom, dimana dari hitungan WSA memiliki nilai besar urutan kedua setelah $U$-bottom akan tetapi pada perhitungan hambatan terletak pada urutan ketiga setelah Hard chin bottom, dengan tidak merekomendasikan Round flat bottom maupun Round bottom, meskipun memiliki nilai hambatan kasko kecil akan tetapi kemampuan volume ruang muat pun lebih kecil.

\section{KESIMPULAN DAN SARAN}

\section{Kesimpulan}

Dari hasil pengujian dan hasil perhitungan berupa grafik maka ada dua tipe lambung kapal yang dapat menjadi perhatian, yaitu tipe kapal dengan lambung akatsuki bottom dan hard chin bottom. Pada kapal dengan tipe kasko lambung akatsuki bottom memiliki volume ruang muat hasil tangkapan dengan luas $59.846 \mathrm{~m}^{3}$ dan tahanan kapal sebesar 1,075 ton, sedangkan pada hard chin bottom dengan luas volume ruang muat sebesar 56,689 $\mathrm{m}^{3}$ dengan besar tahanan kapal sebesar 1,103 ton lebih besar dari pada akatsuki bottom, maka dengan membandingkan kedua tipe kasko lambung kapal tersebut memiliki luas lambung kapal yang besar dan memiliki tahanan yang kecil adalah dengan tipe kapal akatsuki bottom.

\section{Saran}

Kapal ikan memiliki beberapa kesamaan berdasarkan pengoperasian, yang membedakan ialah bentukan kasko lambung kapal, terutama bentukan di bawah permukaan air, sehingga perlu dilakukan kajian lebih lanjut terkait kinerja kapal berdasarkan kemampuan sebuah kapal dalam menampung hasil tangkapannya sebanyak mungkin dengan operasional yang optimal dikaji berdasarkan tahanan kapal yang sekecil mungkin untuk mendapatkan keuntungan sebesar-besarnya dari hasil penangkapan ikan dikurangi biaya operasional (bahan bakar)terhadap laju kapal menuju daerah penangkapan.

\section{DAFTAR PUSTAKA}

Fyson J. 1985. Design of Small Fishing Vessels. England (GB): Fishing News Book.

[BKI] Biro Klasifikasi Indonesia. 2007 . Rules For The Clasification and Construction of seagoing stell ship, Vol II, Vol III, Vol IV. Jakarta (ID): BKI.

Poehls H. 1979. Ship Design and Ship Theory. Germany (DE): University Of Hannover.

Rouf ARA. 2004. Bentuk kasko dan pengaruhnya terhadap tahanan kasko kapal ikan [skripsi]. Bogor (ID). Institut Pertanian Bogor. 